\title{
The World Health Organization Guidelines on Hand Hygiene in Health Care and Their Consensus Recommendations
}

\author{
Didier Pittet, MD, MS; Benedetta Allegranzi, MD; John Boyce, MD; for the World Health Organization World Alliance \\ for Patient Safety First Global Patient Safety Challenge Core Group of Experts
}

\begin{abstract}
The World Health Organization's Guidelines on Hand Hygiene in Health Care have been issued by WHO Patient Safety on 5 May 2009 on the occasion of the launch of the Save Lives: Clean Your Hands initiative. The Guidelines represent the contribution of more than 100 international experts and provide a comprehensive overview of essential aspects of hand hygiene in health care, evidence- and consensusbased recommendations, and lessons learned from testing their Advanced Draft and related implementation tools.
\end{abstract}

Infect Control Hosp Epidemiol 2009; 30:611-622

The World Health Organization (WHO) First Global Patient Safety Challenge, launched in October $2005^{1}$ and aimed at reducing healthcare-associated infection worldwide, identified the promotion of hand hygiene practices in health care as a priority measure and the entry point to improve infection control in Member States. ${ }^{2}$ In April 2006, the WHO World Alliance for Patient Safety issued the Advanced Draft of the WHO Guidelines on Hand Hygiene in Health Care. ${ }^{3}$ The document was developed with the contribution of more than 100 international experts with the objective of providing a comprehensive overview of essential aspects of hand hygiene in health care and evidence- and consensus-based recommendations for successful practice promotion. To achieve this objective, systematic reviews of the literature using PubMed, Ovid, MEDLINE, Embase, and the Cochrane Library were conducted, as well as referring to national and international guidelines and textbooks; task forces dedicated to specific topics were established; and three consultations of a core group of experts were held at WHO Headquarters.

In parallel to the production of the Advanced Draft, an implementation strategy (WHO Multimodal Hand Hygiene Improvement Strategy [http://www.who.int/gpsc/en/]) was developed, together with a wide range of tools (Pilot Implementation Pack) to help healthcare settings translate the guidelines into practice. A key element of the implementation strategy is a very innovative concept, "My five moments for hand hygiene" (Figure 1). It integrates the indications for hand hygiene in five essential moments during the sequence of healthcare delivery and facilitates understanding and ap- propriate practice performance. According to WHO recommendations for guideline preparation, a test phase of the Advanced Draft guidelines was undertaken by using the implementation strategy and tools in eight pilot healthcare settings in seven countries representing all WHO regions worldwide. The objectives of this testing were: to provide local data on the resources required to carry out the recommendations; to generate information on feasibility, validity, reliability, and cost effectiveness of the interventions; and to adapt and refine proposed implementation strategies. Other healthcare settings around the world volunteered to participate autonomously in the test phase and provided WHO with feedback on implementation.

Starting in 2007, an update of the evidence through a review of the literature was performed up to June 2008. In 2008 , an analysis of data and an evaluation of lessons learned from testing sites were conducted. The WHO Guidelines on Hand Hygiene in Health Care have now been finalized and include lessons learned from testing, updated evidence, and expert consensus through two further consultations. External and internal reviewers provided contributions and comments on both the Advanced Draft and the final Guidelines.

The WHO Guidelines on Hand Hygiene in Health Care provide healthcare workers (HCWs), hospital administrators, and health authorities with a thorough review of evidence on hand hygiene in health care and specific recommendations to improve practices and reduce the transmission of pathogenic microorganisms to patients and HCWs. They are intended to be implemented in any situation in which health

From the Infection Control Program, University of Geneva Hospitals and Faculty of Medicine (D.P.), and the World Alliance for Patient Safety, World Health Organization (D.P., B.A.), Geneva, Switzerland; and the Hospital of Saint Raphael, Yale University School of Medicine, New Haven, Connecticut (J.B.). Members of the World Health Organization World Alliance for Patient Safety First Global Patient Safety Challenge Core Group of Experts are listed at the end of the text.

Received April 27, 2009; accepted May 7, 2009; electronically published June 8, 2009.

(C) 2009 by World Health Organization All rights reserved. 0899-823X/2009/3007-0001 DOI: 10.1086/600379 


\section{My 5 moments for HAND HYGIENE}

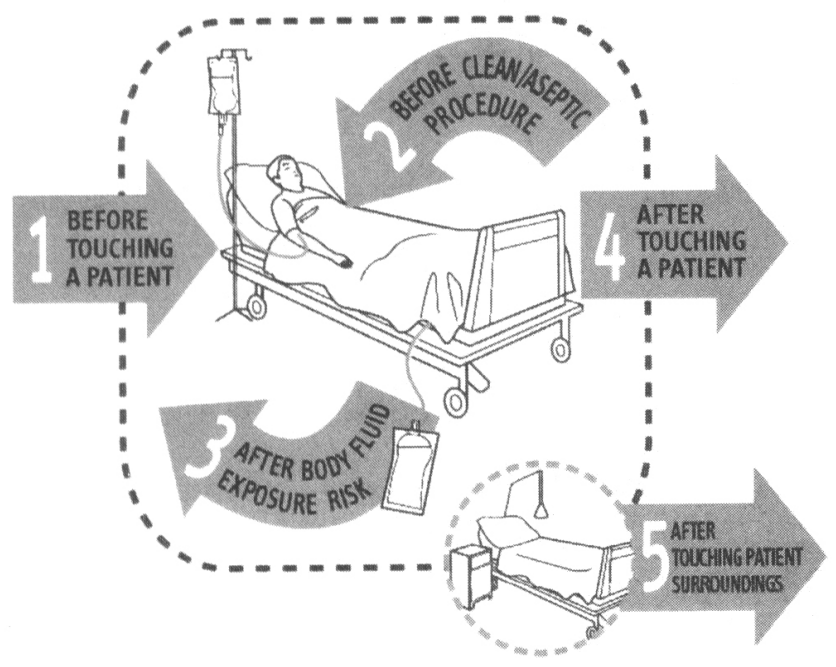

FIGURE 1. The "My 5 moments for hand hygiene" concept (adapted from Sax et al. ${ }^{4}$ ).

care is delivered either to a patient or to a specific group in a population and in all settings where health care is permanently or occasionally performed, including home care by birth attendants.

In comparison with other international or national guidelines, the added values of the WHO guidelines are many: they bring a global perspective; they represent the challenge to bridge the gap between developing and developed countries, irrespective of resources available; and their feasibility has been tested in settings with different cultural backgrounds $s^{5}$ and development levels. ${ }^{6}$ Indeed, the WHO Guidelines explore many innovative aspects, such as religious and cultural aspects, promotion on a national scale, and social marketing. Attention has been paid to some critical topics, particularly safety issues, infrastructures required for hand hygiene, and strategies for improvement.

These Guidelines and the associated WHO Multimodal Hand Hygiene Improvement Strategy and Implementation Toolkit, updated and revised on the basis of data and lessons learned from testing, are designed to offer healthcare facilities in Member States a conceptual framework and practical tools for the application of recommendations in practice at the bedside.

Recommendations were formulated on the basis of the evidence described in the various sections and discussed in depth during the expert core group consultations. In addition to expert consensus, the criteria developed by the Healthcare Infection Control Practices Advisory Committee (HICPAC) of the United States Centers for Disease Control and Prevention $(C D C)$ were used to categorize the consensus rec- ommendations. It is anticipated that the recommendations in these Guidelines will remain valid until 2011, and the Patient Safety Department at WHO headquarters is committed to ensuring that the Guidelines are updated every two to three years.

The WHO Guidelines on Hand Hygiene in Health Care ${ }^{7}$ together with the Implementation Toolkit have been available since 5 May 2009 on the occasion of the launch of the "Save Lives: Clean Your Hands" initiative (http://www.who.int/ gpsc/en/). Based on the promising success observed with the Advanced Draft, these Guidelines are expected to be adopted as the gold standard for hand hygiene in many countries and healthcare settings worldwide. While ensuring consistency with the Guidelines' recommendations, individual adaptation according to local regulations, settings, needs, and resources is desirable.

The Guidelines Consensus Recommendations and their ranking system for evidence are detailed below.

\section{RANKING SYSTEM FOR EVIDENCE}

The consensus recommendations listed below (Sections 1-9) are categorized according to the CDC/HICPAC system, adapted as follows:

- Category IA. Strongly recommended for implementation and strongly supported by well-designed experimental, clinical, or epidemiological studies.

- Category IB. Strongly recommended for implementation and supported by some experimental, clinical, or epidemiological studies and a strong theoretical rationale.

- Category IC. Required for implementation, as mandated by federal and/or state regulation or standard.

- Category II. Suggested for implementation and supported by suggestive clinical or epidemiological studies or a theoretical rationale or a consensus by a panel of experts.

\section{RECOMMENDATIONS}

1. Indications for hand hygiene

A. Wash hands with soap and water when visibly dirty or visibly soiled with blood or other body fluids (IB) or after using the toilet (II) ${ }^{8-18}$

B. If exposure to potential spore-forming pathogens is strongly suspected or proven, including outbreaks of Clostridium difficile, handwashing with soap and water is the preferred means (IB).$^{19-22}$

C. Use an alcohol-based handrub as the preferred means for routine hand antisepsis in all other clinical situations described in items $D(a)$ to $D(f)$ listed below, if hands are not visibly soiled (IA). ${ }^{23-31}$ If alcohol-based handrub is not obtainable, wash hands with soap and water (IB)..$^{25,32,33}$ 
D. Perform hand hygiene:

a) before and after touching the patient (IB); $;^{34-43}$

b) before handling an invasive device for patient care, regardless of whether or not gloves are used (IB); ${ }^{44}$

c) after contact with body fluids or excretions, mucous membranes, non-intact skin, or wound dressings (IA); $;^{8,40,42,45}$

d) if moving from a contaminated body site to another body site during care of the same patient (IB); ${ }^{35,36,39,42,45}$

e) after contact with inanimate surfaces and objects (including medical equipment) in the immediate vicinity of the patient (IB); $;^{35,39,41,}$ 42,45-49

f) after removing sterile (II) or non-sterile (IB) gloves. ${ }^{35,50-53}$

Indications for hand hygiene at the point of care are integrated in Figure 1 that illustrates the concept of "My five moments for hand hygiene". ${ }^{4}$

E. Before handling medication or preparing food perform hand hygiene using an alcohol-based handrub or wash hands with either plain or antimicrobial soap and water (IB). ${ }^{11-14}$

F. Soap and alcohol-based handrub should not be used concomitantly (II)..$^{54,55}$

2. Hand hygiene technique

A. Apply a palmful of alcohol-based handrub and cover all surfaces of the hands. Rub hands until dry (IB) (Figure 2A). ${ }^{56,57}$

$B$. When washing hands with soap and water, wet hands with water and apply the amount of product necessary to cover all surfaces (Figure 2B). Rinse hands with water and dry thoroughly with a singleuse towel. Use clean, running water whenever possible. Avoid using hot water, as repeated exposure to hot water may increase the risk of dermatitis (IB) ${ }^{58-60}$ Use towel to turn off tap/faucet (IB). ${ }^{61-65}$ Dry hands thoroughly using a method that does not recontaminate hands. Make sure towels are not used multiple times or by multiple people (IB). ${ }^{66-69}$

C. Liquid, bar, leaf or powdered forms of soap are acceptable. When bar soap is used, small bars of soap in racks that facilitate drainage should be used to allow the bars to dry (II) ${ }^{70-76}$

3. Recommendations for surgical hand preparation

A. Remove rings, wrist-watch, and bracelets before beginning surgical hand preparation (II). ${ }^{77-81} \mathrm{Ar}-$ tificial nails are prohibited (IB). ${ }^{82-86}$
B. Sinks should be designed to reduce the risk of splashes (II). ${ }^{87,88}$

C. If hands are visibly soiled, wash hands with plain soap before surgical hand preparation (II). Remove debris from underneath fingernails using a nail cleaner, preferably under running water (II) ${ }^{89}$

D. Brushes are not recommended for surgical hand preparation (IB). ${ }^{90.96}$

E. Surgical hand antisepsis should be performed using either a suitable antimicrobial soap or suitable alcohol-based handrub, preferably with a product ensuring sustained activity, before donning sterile gloves (IB). ${ }^{95,97-103}$

F. If quality of water is not assured in the operating theatre, surgical hand antisepsis using an alcoholbased handrub is recommended before donning sterile gloves when performing surgical procedures (II). ${ }^{95,98,100,104}$

G. When performing surgical hand antisepsis using an antimicrobial soap, scrub hands and forearms for the length of time recommended by the manufacturer, typically 2-5 minutes. Long scrub times (e.g. 10 minutes) are not necessary (IB). ${ }^{91,103,105-111}$

$H$. When using an alcohol-based surgical handrub product with sustained activity, follow the manufacturer's instructions for application times. Apply the product to dry hands only (IB). ${ }^{112,113}$ Do not combine surgical hand scrub and surgical handrub with alcohol-based products sequentially (II). ${ }^{54}$

I. When using an alcohol-based handrub, use sufficient product to keep hands and forearms wet with the handrub throughout the surgical hand preparation procedure (IB). ${ }^{114-116}$

J. After application of the alcohol-based handrub as recommended, allow hands and forearms to dry thoroughly before donning sterile gloves (IB). ${ }^{95,100}$

4. Selection and handling of hand hygiene agents

A. Provide HCWs with efficacious hand hygiene products that have low irritancy potential (IB). ${ }^{24}$, 62,117-123

B. To maximize acceptance of hand hygiene products by HCWs, solicit their input regarding the skin tolerance, feel, and fragrance of any products under consideration (IB). 23,24,120,124-129 Comparative evaluations may greatly help in this process. ${ }^{19,}$, 124, 125,130

C. When selecting hand hygiene products

a) determine any known interaction between products used to clean hands, skin care products, and the types of glove used in the institution (II); ${ }^{131,132}$ 


\section{Hand Hygiene Technique with Alcohol-Based Formulation}

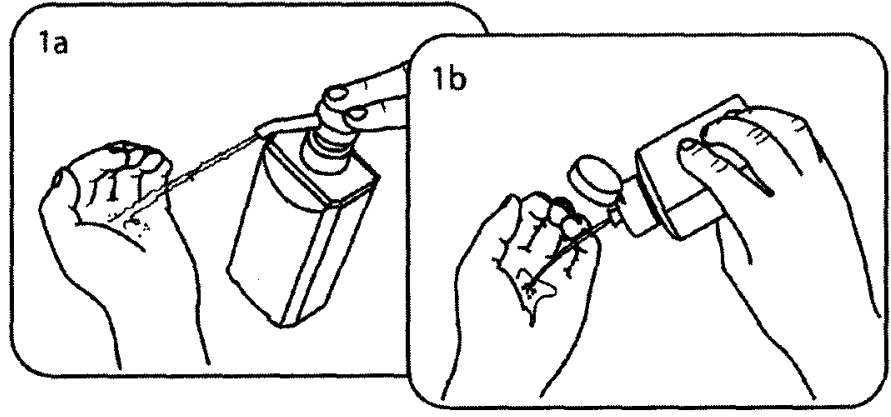

Apply a palmfull of the product in a cupped hand and cover all surfaces.

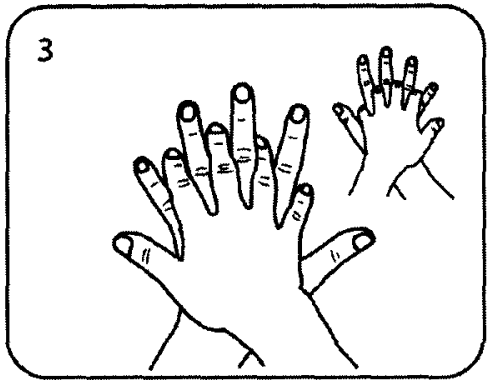

right palm over left dorsum with interlaced fingers and vice versa

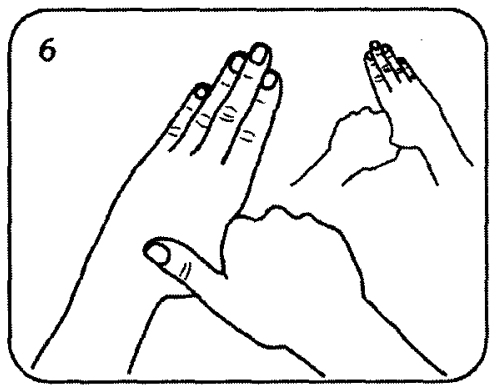

rotational rubbing of left thumb clasped in right palm and vice versa

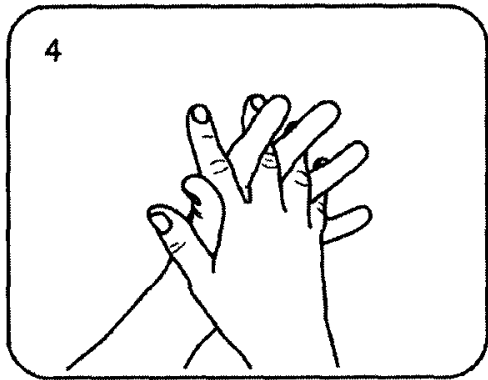

palm to paim with fingers interlaced



rotational rubbing, backwards and forwards with clasped fingers of right hand in left palm and vice versa



Rub hands paim to paim


....once dry, your hands are safe.

FIGURE 2A. Hand hygiene technique with an alcohol-based formulation. ${ }^{3}$

b) solicit information from manufacturers about the risk of product contamination (IB); ${ }^{133-135}$

c) ensure that dispensers are accessible at the point of care (IB); $;^{28,136}$

d) ensure that dispensers function adequately and reliably and deliver an appropriate volume of the product (II); $;^{25,137}$

e) ensure that the dispenser system for alcoholbased handrubs is approved for flammable materials (IC);

f) solicit and evaluate information from manufacturers regarding any effect that hand lo- tions, creams, or alcohol-based handrubs may have on the effects of antimicrobial soaps being used in the institution (IB) $;^{131,138,139}$

g) cost comparisons should only be made for products that meet requirements for efficacy, skin tolerance, and acceptability (II). ${ }^{129,140}$

D. Do not add soap (IA) or alcohol-based formulations (II) to a partially empty soap dispenser. If soap dispensers are reused, follow recommended procedures for cleansing. ${ }^{141,142}$ 


\section{Handwashing Technique with Soap and Water}



Wet hands with water



apply enough soap to cover all surfaces

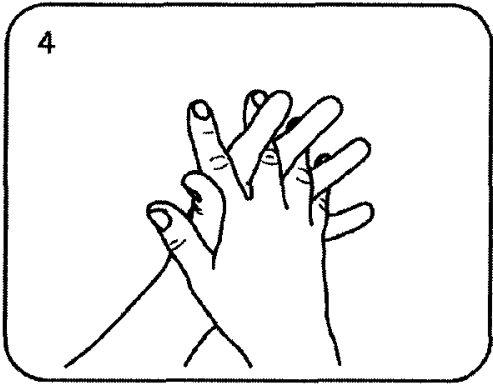

palm to palm with fingers interlaced

right palm over left dorsum with interlaced fingers and vice versa

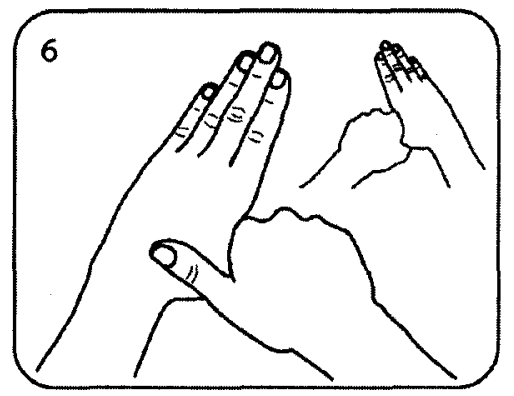

rotational rubbing of left thumb clasped in right palm and vice versa

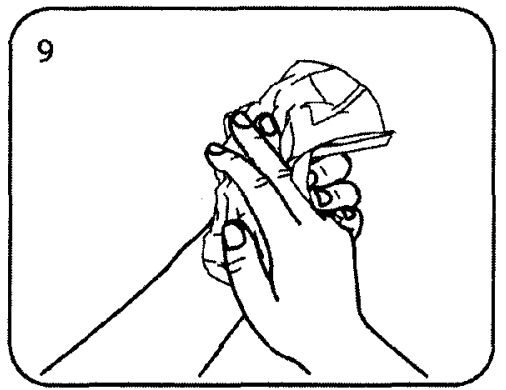

dry thoroughly with a single use towel

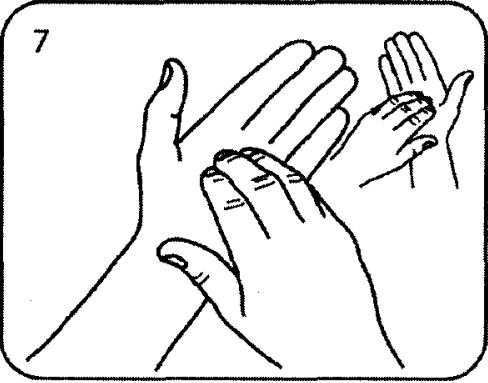

rotational rubbing, backwards and forwards with clasped fingers of right hand in left palm and vice versa



use towel to turn off faucet/tap

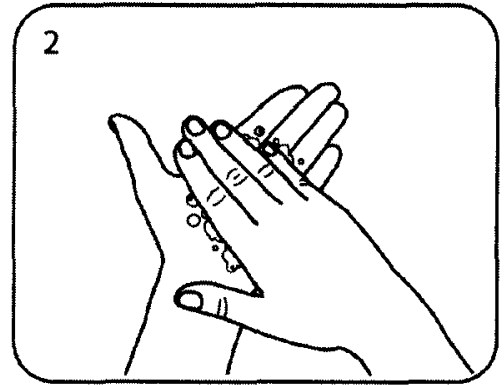

rub hands palm to palm

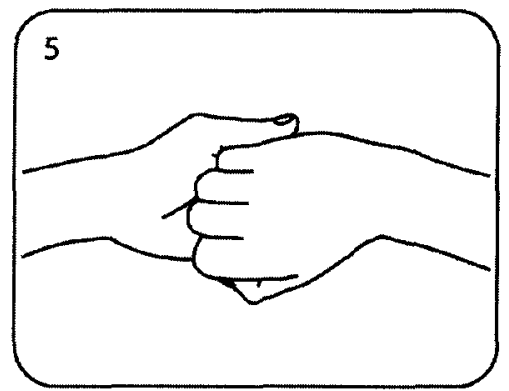

backs of fingers to opposing palms with fingers interlocked

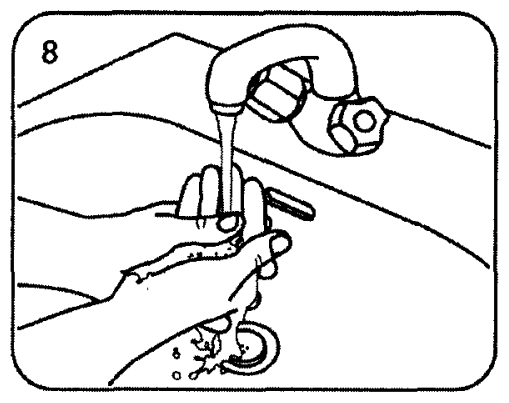

rinse hands with water

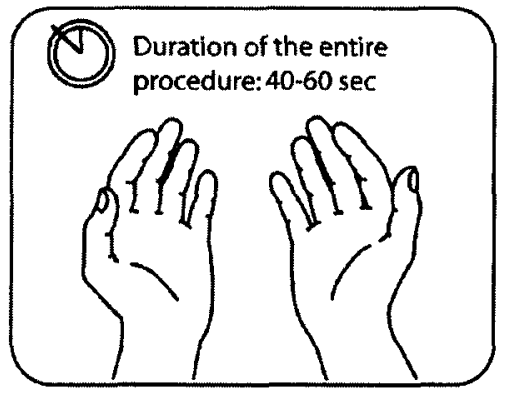

...and your hands are safe.

FIGURE 2B. Handwashing technique with soap and water. ${ }^{3}$ 


\section{Skin care}

A. Include information regarding hand-care practices designed to reduce the risk of irritant contact dermatitis and other skin damage in education programmes for HCWs (IB). ${ }^{143,144}$

B. Provide alternative hand hygiene products for HCWs with confirmed allergies or adverse reactions to standard products used in the healthcare setting (II).

C. Provide HCWs with hand lotions or creams to minimize the occurrence of irritant contact dermatitis associated with hand antisepsis or handwashing (IA)..$^{120,121,144-147}$

D. When alcohol-based handrub is available in the healthcare facility for hygienic hand antisepsis, the use of antimicrobial soap is not recommended (II).

E. Soap and alcohol-based handrub should not be used concomitantly (II) ${ }^{54}$

6. Use of gloves

A. The use of gloves does not replace the need for hand hygiene by either handrubbing or handwashing (IB). ${ }^{35,50-52,148-150}$

B. Wear gloves when it can be reasonably anticipated that contact with blood or other potentially infectious materials, mucous membranes, or non-intact skin will occur (IC). ${ }^{151-153}$

C. Remove gloves after caring for a patient. Do not wear the same pair of gloves for the care of more than one patient (IB). ${ }^{35,41,50-52,154,155}$

D. When wearing gloves, change or remove gloves during patient care if moving from a contaminated body site to either another body site (including non-intact skin, mucous membrane or medical device) within the same patient or the environment (II)..$^{50,51,156}$

E. The reuse of gloves is not recommended (IB). ${ }^{157}$ In the case of glove reuse, implement the safest reprocessing method (II). ${ }^{158}$

\section{Other aspects of hand hygiene}

A. Do not wear artificial fingernails or extenders when having direct contact with patients (IA) ${ }^{82}$, 86,159-162

B. Keep natural nails short (tips less than $0.5 \mathrm{~cm}$ long or approximately $1 / 4$ inch) (II). ${ }^{160}$

8. Educational and motivational programmes for healthcare workers

A. In hand hygiene promotion programmes for
HCWs, focus specifically on factors currently found to have a significant influence on behaviour, and not solely on the type of hand hygiene products. The strategy should be multifaceted and multimodal and include education and senior executive support for implementation (IA). ${ }^{25,57,163-179}$

B. Educate HCWs about the type of patient-care activities that can result in hand contamination and about the advantages and disadvantages of various methods used to clean their hands (II). ${ }^{25,57,168,178-185}$

C. Monitor HCWs' adherence to recommended hand hygiene practices and provide them with performance feedback (IA). ${ }^{25,128,165,166,168,178,180-182,184,186,187}$

D. Encourage partnerships between patients, their families, and HCWs to promote hand hygiene in healthcare settings (II)..$^{188-190}$

9. Governmental and institutional responsibilities

\subsection{For healthcare administrators}

A. It is essential that administrators ensure conditions are conducive to the promotion of a multifaceted, multimodal hand hygiene strategy and an approach that promotes a patient safety culture by implementation of points $\mathrm{B}-$ I below.

B. Provide HCWs with access to a safe, continuous water supply at all outlets and access to the necessary facilities to perform handwashing (IB). ${ }^{178,191,192}$

C. Provide HCWs with a readily accessible alcohol-based handrub at the point of patient care (IA). . $5,27,28,30,193-197^{-19}$

D. Make improved hand hygiene adherence (compliance) an institutional priority and provide appropriate leadership, administrative support, financial resources, and support for hand hygiene and other infection prevention and control activities (IB). ${ }^{25,163,168,170 \text {. }}$ 198

E. Ensure HCWs have dedicated time for infection control training, including sessions on hand hygiene (II)..$^{172,199}$

F. Implement a multidisciplinary, multifaceted and multimodal programme designed to improve adherence of HCWs to recommended hand hygiene practices (IB)..$^{25,163,200}$

G. With regard to hand hygiene, ensure that the water supply is physically separated from drainage and sewerage within the healthcare setting, and provide routine system monitoring and management (IB). ${ }^{201}$

H. Provide strong leadership and support for 
hand hygiene and other infection prevention and control activities (II). ${ }^{163}$

I. Alcohol-based handrub production and storage must adhere to the national safety guidelines and local legal requirements (II).

\subsection{For national governments}

A. Make improved hand hygiene adherence a national priority and consider provision of a funded, coordinated implementation programme, while ensuring monitoring and long-term sustainability (II). ${ }^{202-205}$

B. Support strengthening of infection control capacities within healthcare settings (II) ${ }^{199,206,207}$

C. Promote hand hygiene at the community level to strengthen both self-protection and the protection of others (II) ${ }^{16-18,208-211}$

D. Encourage healthcare settings to use hand hygiene as a quality indicator (Australia, Belgium, France, Scotland, USA) (II). ${ }^{185,212}$

\section{WORLD HEALTH ORGANIZATION WORLD}

\section{ALLIANCE FOR PATIENT SAFETY FIRST \\ GLOBAL PATIENT SAFETY CHALLENGE \\ CORE GROUP OF EXPERTS}

Didier Pittet (Lead; Switzerland), John Boyce (United States), Barry Cookson (United Kingdom), Nizam Damani (United Kingdom), Don Goldmann (United States), Lindsay Grayson (Australia), Elaine Larson (United States), Geeta Mehta (India), Ziad Memish (Saudi Arabia), Hervé Richet (France), Manfred Rotter (Austria), Syed Sattar (Canada), Hugo Sax (Switzerland), Wing Hong Seto (Hong Kong, SAR [China]), Andreas Voss (The Netherlands), and Andreas Widmer (Switzerland).

\section{ACKNOWLEDGMENTS}

We thank all members of the World Health Organization First Global Patient Safety Challenge team and the Infection Control Program, University of Geneva Hospitals, in particular Rosemary Sudan for outstanding editorial assistance in all steps of the development and preparation of the Guidelines.

Potential conflicts of interest. All authors report no conflicts of interest relevant to this work.

Address reprint requests to Professor Didier Pittet, MD, MS, Infection Control Program, University of Geneva Hospitals and Faculty of Medicine, 4 Rue Gabrielle Perret-Gentil, 1211 Geneva 14, Switzerland (didier.pittet@ hcuge.ch).

The World Health Organization takes no responsibility for the information provided or the views expressed in this paper.

\section{REFERENCES}

1. Pittet D, Donaldson L. Clean Care is Safer Care: a worldwide priority. Lancet $2005 ; 366: 1246-1247$.

2. Pittet D, Donaldson L. Clean Care is Safer Care: the first global challenge of the WHO World Alliance for Patient Safety. Infect Control Hosp Epidemiol 2005; 26:891-894.

3. World Health Organization. WHO Guidelines for Hand Hygiene in Health Care (Advanced Draft). Geneva, Switzerland: World Health Organization, 2006.

4. Sax H, Allegranzi B, Uckay I, Larson E, Boyce J, Pittet D. 'My five moments for hand hygiene': a user-centred design approach to understand, train, monitor and report hand hygiene. I Hosp Infect 2007; 67: 9-21.

5. Ahmed QA, Memish ZA, Allegranzi B, Pittet D. Muslim health-care workers and alcohol-based handrubs. Lancet 2006; 367:1025-1027.

6. Storr J, Pittet D. Re: help or hindrance? Is current infection control advice applicable in low- and middle-income countries? A review of the literature. Am I Infect Control 2008; 36:499-501.

7. World Health Organization. WHO Guidelines on Hand Hygiene in Health Care. Geneva, Switzerland: World Health Organization Press, 2009.

8. Larson E. A causal link between handwashing and risk of infection? Examination of the evidence. Infect Control 1988; 9:28-36.

9. Larson EL, Morton HE. Alcohols. In: Block SS, ed. Disinfection, sterilization and preservation. 4th ed. Philadelphia, PA: Lea and Febiger, 1991:191-203.

10. Denton GW. Chlorhexidine. In: Block SS, ed. Disinfection, sterilization and preservation. 4th ed. Philadelphia, PA: Lea and Febiger, 1991:274289.

11. Drusin LM, Sohmer M, Groshen SL, Spiritos MD, Senterfit LB, Christenson WN. Nosocomial hepatitis $A$ infection in a paediatric intensive care unit. Arch Dis Child 1987; 62:690-695.

12. Doebbeling BN, Li N, Wenzel RP. An outbreak of hepatitis A among health care workers: risk factors for transmission. Am J Public Health 1993; 83:1679-1684.

13. Standaert SM, Hutcheson RH, Schaffner W. Nosocomial transmission of Salmonella gastroenteritis to laundry workers in a nursing home. Infect Control Hosp Epidemiol 1994; 15:22-26.

14. Rodriguez EM, Parrott C, Rolka H, Monroe SS, Dwyer DM. An outbreak of viral gastroenteritis in a nursing home: importance of excluding ill employees. Infect Control Hosp Epidemiol 1996; 17:587-592.

15. Schaffner W, Lefkowitz LB, Goodman IS, Koenig MG. Hospital outbreak of infections with group A streptococci traced to an asymptomatic anal carrier. New Engl J Med 1969; 280:1224-1225.

16. Shahid NS, Greenough WB, Samadi AR, Huq MI. Hand washing with soap reduces diarrhoea and spread of bacterial pathogens in a Bangladesh village. J Diarrhoral Dis Res 1996; 14:85-89.

17. Luby SP, Agboatwalla M, Painter J, Altaf A, Billhimer WL, Hoekstra RM. Effect of intensive handwashing promotion on childhood diarrhea in high-risk communities in Pakistan: a randomized controlled trial. JAMA 2004; 291:2547-2554.

18. Ejemot R, Ehiri J, Meremikwu M, Critchley J. Hand washing for preventing diarrhoea. Cochrane Database Syst Rev 2008:CD004265.

19. Bettin K, Clabots C, Mathie P, Willard K, Gerding DN. Effectiveness of liquid soap vs chlorhexidine gluconate for the removal of Clostridium difficile from bare hands and gloved hands. Infect Control Hosp Epidemiol 1994; 15:697-702.

20. Hubner NO, Kampf G, Loffler H, Kramer A. Effect of a 1 min hand wash on the bactericidal efficacy of consecutive surgical hand disinfection with standard alcohols and on skin hydration. Int J Hyg Environ Health 2006; 209:285-291.

21. Weber DJ, Sickbert-Bennett E, Gergen MF, Rutala WA. Efficacy of selected hand hygiene agents used to remove Bacillus atrophaeus (a surrogate of Bacillus anthracis) from contaminated hands. JAMA 2003; 289: $1274-1277$. 
22. Russell AD. Chemical sporicidal and sporostatic agents. In: Block SS, ed. Disinfection, sterilization and preservation. 4th ed. Philadelphia, PA: Lea and Febiger, 1991:365-376.

23. Larson EL, Eke PI, Laughon BE. Efficacy of alcohol-based hand rinses under frequent-use conditions. Antimicrob Agents Chemother 1986; 30: 542-544.

24. Larson EL, Aiello AE, Bastyr J, et al. Assessment of two hand hygiene regimens for intensive care unit personnel. Crit Care Med 2001; 29:944951.

25. Pittet D, Hugonnet $S$, Harbarth $S$, et al. Effectiveness of a hospitalwide programme to improve compliance with hand hygiene. Lancet $2000 ; 356: 1307-1312$.

26. Widmer AF. Replace hand washing with use of a waterless alcohol hand rub? Clin Infect Dis 2000; 31:136-143.

27. Maury E, Alzieu M, Baudel JL, et al. Availability of an alcohol solution can improve hand disinfection compliance in an intensive care unit. Am J Respir Crit Care Med 2000; 162:324-327.

28. Bischoff WE, Reynolds TM, Sessler CN, Edmond MB, Wenzel RP. Handwashing compliance by health care workers: the impact of introducing an accessible, alcohol-based hand antiseptic. Arch Intern Med 2000; 160:1017-1021.

29. Boyce JM. Scientific basis for handwashing with alcohol and other waterless antiseptic agents. In: Rutala WA, ed. Disinfection, sterilization and antisepsis: principles and practices in healthcare facilities. Washington, DC: Association for Professionals in Infection Control and Epidemiology, Inc., 2001:140-151.

30. Graham M. Frequency and duration of handwashing in an intensive care unit. Am J Infect Control 1990; 18:77-81.

31. Picheansathian W. A systematic review on the effectiveness of alcoholbased solutions for hand hygiene. Int I Nurs Pract 2004; 10:3-9.

32. Maki DG. The use of antiseptics for handwashing by medical personnel. I Chemother 1989; 1 (suppl):3-11.

33. Massanari RM, Hierholzer WJ Jr. A crossover comparison of antiseptic soaps on nosocomial infection rates in intensive care units. Am J Infect Control 1984; 12:247-248.

34. Mortimer EA, Lipsitz PJ, Wolinsky E, et al. Transmission of staphylococci between newborns. Am I Dis Child 1962; 104:289-295.

35. Pessoa-Silva CL, Dharan $S$, Hugonnet $S$, et al. Dynamics of bacterial hand contamination during routine neonatal care. Infect Control Hosp Epidemiol 2004; 25:192-197.

36. Ehrenkranz NJ, Alfonso BC. Failure of bland soap handwash to prevent hand transfer of patient bacteria to urethral catheters. Infect Control Hosp Epidemiol 1991; 12:654-662.

37. McFarland LV, Mulligan ME, Kwok RY, Stamm WE. Nosocomial acquisition of Clostridium difficile infection. New Engl J Med 1989; 320: 204-210.

38. Casewell M, Phillips I. Hands as route of transmission for Klebsiella species. BMJ 1977; 2:1315-1317.

39. Duckro AN, Blom DW, Lyle EA, Weinstein RA, Hayden MK. Transfer of vancomycin-resistant enterococci via health care worker hands. Arch Intern Med 2005; 165:302-307.

40. Semmelweis I. Die Aetiologie, der Begriff und die Prophylaxis des Kindbettfiebers [The etiology, concept and prophylaxis of childbed fever]. Pest, Hungary; Wien, Austria; und Leipzig, Germany: Hartleben VerlagExpedition, 1861

41. Hayden MK, Blom DW, Lyle EA, Moore CG, Weinstein RA. Risk of hand or glove contamination after contact with patients colonized with vancomycin-resistant Enterococcus or the colonized patients' environment. Infect Control Hosp Epidemiol 2008; 29:149-154.

42. Ojajärvi J. Effectiveness of hand washing and disinfection methods in removing transient bacteria after patient nursing. I Hyg (London) $1980 ; 85: 193-203$.

43. Wendt C, Knautz D, Baum H. Differences in hand hygiene behavior related to the contamination risk of healthcare activities in different groups of health care workers. Infect Control Hosp Epidemiol 2004; 25: 203-206.
44. Hirschmann H, Fux L, Podusel JS, et al. The influence of hand hygiene prior to insertion of peripheral venous catheters on the frequency of complications. J Hosp Infect 2001; 49:199-203.

45. Lucet IC, Rigaud MP, Mentre F, et al. Hand contamination before and after different hand hygiene techniques: a randomized clinical trial. $J$ Hosp Infect 2002; 50:276-280.

46. Samore MH, Venkataraman L, DeGirolami PC, Levin E, Karchmer AW Clinical and molecular epidemiology of sporadic and clustered cases of nosocomial Clostridium difficile diarrhea. Am J Med 1996; 100:32-40.

47. Boyce JM, Potter-Bynoe G, Chenevert C, King T. Environmental contamination due to methicillin-resistant Staphylococcus aureus: possible infection control implications. Infect Control Hosp Epidemiol 1997; 18: 622-627.

48. Ray AJ, Hoyen CK, Taub TF, Eckstein EC, Donskey CJ. Nosocomial transmission of vancomycin-resistant enterococci from surfaces. JAMA 2002; 287:1400-1401.

49. Bhalla A, Pultz NJ, Gries DM, et al. Acquisition of nosocomial pathogens on hands after contact with environmental surfaces near hospitalized patients. Infect Control Hosp Epidemiol 2004; 25:164-167.

50. Olsen RJ, Lynch P, Coyle MB, Cummings J, Bokete T, Stamm WE. Examination gloves as barriers to hand contamination in clinical practice. JAMA 1993; 270:350-353.

51. Tenorio AR, Badri SM, Sahgal NB, et al. Effectiveness of gloves in the prevention of hand carriage of vancomycin-resistant Enterococcus species by health care workers after patient care. Clin Infect Dis 2001; 32: 826-829.

52. Doebbeling BN, Pfaller MA, Houston AK, Wenzel RP. Removal of nosocomial pathogens from the contaminated glove: implications for glove reuse and handwashing. Ann Intern Med 1988; 109:394-398.

53. Eggimann $\mathrm{P}$, Harbarth S, Constantin MN, Touveneau S, Chevrolet JC, Pittet $\mathrm{D}$. Impact of a prevention strategy targeted at vascular-access care on incidence of infections acquired in intensive care. Lancet 2000; 355: 1864-1868.

54. Kampf G, Loffler H. Dermatological aspects of a successful introduction and continuation of alcohol-based hand rubs for hygienic hand disinfection. J Hosp Infect 2003; 55:1-7.

55. Kampf G, Löffler H. Prevention of irritant contact dermatitis among health care workers by using evidence-based hand hygiene practices: a review. Ind Health 2007; 45:645-652.

56. European standard EN 1499. Chemical disinfectants and antiseptics. Hygienic hand wash. Test method and requirements. Brussels, Belgium: European Committee for Standardization, 1997.

57. Widmer AF, Conzelmann M, Tomic M, Frei R, Stranden AM. Introducing alcohol-based hand rub for hand hygiene: the critical need for training. Infect Control Hosp Epidemiol 2007; 28:50-54.

58. Ohlenschlaeger J, Friberg J, Ramsing D, Agner T. Temperature dependency of skin susceptibility to water and detergents. Acta Derm Venereol 1996; 76:274-276.

59. Emilson A, Lindbert M, Forslind B. The temperature effect of in vitro penetration of sodium lauryl sulfate and nickel chloride through human skin. Acta Derm Venereol 1993; 73:203-207.

60. Berardesca E, Vignoli GP, Distante F, Brizzi P, Rabbiosi G. Effects of water temperature on surfactant-induced skin irritation. Contact Dermatitis $1995 ; 32: 83-87$.

61. Larson EL, Eke PI, Wilder MP, Laughon BE. Quantity of soap as a variable in handwashing. Infect Control 1987; 8:371-375.

62. Larson E, Leyden JJ, McGinley KJ, Grove GL, Talbot GH. Physiologic and microbiologic changes in skin related to frequent handwashing. Infect Control 1986; 7:59-63.

63. Larson EL, Laughon BE. Comparison of four antiseptic products containing chlorhexidine gluconate. Antimicrob Agents Chemother 1987; 31: 1572-1574.

64. Taylor LJ. An evaluation of handwashing techniques-1. Nurs Times $1978 ; 74: 54-55$.

65. Mermel LA, Josephson SL, Dempsey J, Parenteau S, Perry C, Magill N. 
Outbreak of Shigella sonnei in a clinical microbiology laboratory. J Clin Microbiol 1997; 35:3163-3165.

66. Patrick DR, Findon G, Miller TE. Residual moisture determines the level of touch-contact-associated bacterial transfer following hand washing. Epidemiol Infect 1997; 119:319-325.

67. Griffith CJ, Malik R, Cooper RA, Looker N, Michaels B. Environmental surface cleanliness and the potential for contamination during handwashing. Am J Infect Control 2003; 31:93-96.

68. Ansari SA, Springthorpe VS, Sattar SA, Tostowaryk W, Wells GA. Comparison of cloth, paper, and warm air drying in eliminating viruses and bacteria from washed hands. Am I Infect Control 1991; 19:243-249.

69. Larson EL, McGinley KJ, Foglia A, et al. Handwashing practices and resistance and density of bacterial hand flora on two pediatric units in Lima, Peru. Am J Infect Control 1992; 20:65-72.

70. Heinze JE, Yackovich F. Washing with contaminated bar soap is unlikely to transfer bacteria. Epidemiol Infect 1988; 101:135-142.

71. Bannan EA, Judge LF. Bacteriological studies relating to handwashing 1: the inability of soap bars to transmit bacteria. Am J Public Health 1965; 55:915-922.

72. McBride ME. Microbial flora of in-use soap products. App Environ Microbiol 1984; 48:338-341.

73. Subbannayya K, Bhat GK, Junu VG, Shetty S, Jisho MG. Can soaps act as fomites in hospitals? J Hosp Infect 2006; 62:244-245.

74. Hegde PP, Andrade AT, Bhat K. Microbial contamination of "in use" bar soap in dental clinics. Indian J Dent Res 2006; 17:70-73.

75. Rabier V, Bataillon S, Jolivet-Gougeon A, Chapplain JM, Beuchee A, Betremieux P. Hand washing soap as a source of neonatal Serratia marcescens outbreak. Acta Paediatr 2008; 97:1381-1385.

76. Das A, Mandal L, Chatterjee SS, Ray P, Marwaha RK. Is hand washing safe? J Hosp Infect 2008; 69:303-304.

77. Hoffman PN, Cooke EM, McCarville MR, Emmerson AM. Micro-organisms isolated from skin under wedding rings worn by hospital staff. BMJ 1985; 290:206-207.

78. Salisbury DM, Hutfilz P, Treen LM, Bollin GE, Gautam S. The effect of rings on microbial load of health care workers' hands. Am J Infect Control 1997; 25:24-27.

79. Field EA, McGowan P, Pearce PK. Rings and watches: should they be removed prior to operative dental procedures? J Dent 1996; 24:65-69.

80. Fagernes $M$, Lingaas $E$, Bjark $P$. Impact of a single plain finger ring on the bacterial load on the hands of healthcare workers. Infect Control Hosp Epidemiol 2007; 28:1191-1195.

81. Wongworawat MD, Jones SG. Influence of rings on the efficacy of hand sanitization and residual bacterial contamination. Infect Control Hosp Epidemiol 2007; 28:351-353.

82. McNeil SA, Foster CL, Hedderwick SA, Kauffman CA. Effect of hand cleansing with antimicrobial soap or alcohol-based gel on microbial colonization of artificial fingernails worn by health care workers. Clin Infect Dis 2001; 32:367-372.

83. Hedderwick SA, McNeil SA, Kauffman CA. Pathogenic organisms associated with artificial fingernails worn by healthcare workers. Infect Control Hosp Epidemiol 2000; 21:505-509.

84. Pottinger J, Burns S, Manske C. Bacterial carriage by artificial versus natural nails. Am J Infect Control 1989; 17:340-344.

85. Passaro DJ, Waring L, Armstrong R, et al. Postoperative Serratia marcescens wound infections traced to an out-of-hospital source. J Infect Dis 1997; 175:992-995.

86. Parry M, Grant B, Yukna M, et al. Candida osteomyelitis and diskitis after spinal surgery: an outbreak that implicates artificial nail use. Clin Infect Dis 2001; 32:352-357.

87. Weber DJ, Rutala WA, Blanchet CN, Jordan M, Gergen MF. Faucet aerators: a source of patient colonization with Stenotrophomonas maltophilia. Am J Infect Control 1999; 27:59-63.

88. Cross DF, Benchimol A, Dimond EG. The faucet aerator- a source of Pseudomonas infection. New Engl J Med 1966; 274:1430-1431.

89. Price PB. The bacteriology of normal skin: a new quantitative test applied to a study of the bacterial flora and the disinfectant action of mechanical cleansing. J Infect Dis 1938; 63:301-318.

90. Furukawa K TT, Suzuki H, Norose Y. Are sterile water and brushes necessary for handwashing before surgery in Japan. J Nippon Med Sch 2005; 72:149-154.

91. Dineen P. An evaluation of the duration of the surgical scrub. Surg Gynecol Obstet 1969; 129:1181-1184.

92. Bornside GH, Crowder VH Jr, Cohn I Jr. A bacteriological evaluation of surgical scrubbing with disposable iodophor-soap impregnated polyurethane scrub sponges. Surgery $1968 ; 64: 743-751$.

93. McBride ME, Duncan WC, Knox JM. An evaluation of surgical scrub brushes. Surg Gynecol Obstet 1973; 137:934-936.

94. Meers PD, Yeo GA. Shedding of bacteria and skin squames after handwashing. J Hyg (London) 1978; 81:99-105.

95. Hobson DW, Woller W, Anderson L, Guthery E. Development and evaluation of a new alcohol-based surgical hand scrub formulation with persistent antimicrobial characteristics and brushless application. Am J Infect Control 1998; 26:507-512.

96. Loeb MB, Wilcox L, Smaill F, Walter S, Duff Z. A randomized trial of surgical scrubbing with a brush compared to antiseptic soap alone. $A m$ J Infect Control 1997; 25:11-15.

97. Boyce JM, Potter-Bynoe G, Opal SM, Dziobek L, Medeiros AA. A common-source outbreak of Staphylococcus epidermidis infections among patients undergoing cardiac surgery. I Infect Dis 1990; 161:493499.

98. Larson EL, Butz AM, Gullette DL, Laughon BA. Alcohol for surgical scrubbing? Infect Control Hosp Epidemiol 1990; 11:139-143.

99. Grinbaum RS, de Mendonca JS, Cardo DM. An outbreak of handscrubbing-related surgical site infections in vascular surgical procedures. Infect Control Hosp Epidemiol 1995; 16:198-202.

100. Mulberry G, Snyder AT, Heilman J, Pyrek J, Stahl J. Evaluation of a waterless, scrubless chlorhexidine gluconate/ethanol surgical scrub for antimicrobial efficacy. Am J Infect Control 2001; 29:377-382.

101. Rotter ML, Kampf G, Suchomel M, Kundi M. Population kinetics of the skin flora on gloved hands following surgical hand disinfection with 3 propanol-based hand rubs: a prospective, randomized, double-blind trial. Infect Control Hosp Epidemiol 2007; 28:346-350.

102. Gupta C, Czubatyj AM, Briski LE, Malani AK. Comparison of two alcohol-based surgical scrub solutions with an iodine-based scrub brush for presurgical antiseptic effectiveness in a community hospital. I Hosp Infect 2007; 65:65-71.

103. Tanner J, Swarbrook S, Stuart J. Surgical hand antisepsis to reduce surgical site infection. Cochrane Database Syst Rev 2008:CD004288.

104. Squier C, Yu VL, Stout JE. Waterborne nosocomial infections. Curr Infect Dis Rep 2000; 2:490-496.

105. Galle PC, Homesley HD, Rhyne AL. Reassessment of the surgical scrub. Surg Gynecol Obstet 1978; 147:215-218.

106. Hingst V, Juditzki I, Heeg P. Evaluation of the efficacy of surgical hand disinfection following a reduced application time of 3 instead of 5 minutes. J Hosp Infect 1992; 20:79-86.

107. Pereira LJ, Lee GM, Wade KJ. The effect of surgical handwashing routines on the microbial counts of operating room nurses. Am J Infect Control 1990; 18:354-364.

108. Lowbury EJL, Lilly HA. Disinfection of the hands of surgeons and nurses. BMJ 1960; 1:1445-1450.

109. O'Farrell DA, Kenny G, O'Sullivan M, Nicholson P, Stephens M, Hone R. Evaluation of the optimal hand-scrub duration prior to total hip arthroplasty. J Hosp Infect 1994; 26:93-98.

110. O'Shaughnessy M, O'Maley VP, Corbett G. Optimum duration of surgical scrub-time. Br J Surg 1991; 78:685-686.

111. Wheelock SM, Lookinland S. Effect of surgical hand scrub time on subsequent bacterial growth. AORN J 1997; 65:1087-1098.

112. Heeg P, Ulmer R, Schwenzer N. Verbessern Haendewaschen und Verwendung der Handbuerste das Ergebnis der Chirurgischen Haendedesinfektion? [Does handwashing and use of brush improve the result of surgical hand disinfection?]. Hyg Mediz 1988; 13:270-272. 
113. Rotter ML, Koller W. Effekt der sequentiellen Anwendung von Chlorhexidinseife und einer alkoholischen CHX-Praeparation versus Flüssigseife und einer solchen Praeparation bei der Chirurgischen Haendedesinfektion. [Effect of sequential use of chlorhexidine soap and an alcoholic-chlorhexidine preparation versus liquid soap and alcoholicchlorhexidine preparation on surgical hand disinfection]. Hyg Mediz 1990; 15:437-404.

114. Kampf G, Ostermeyer C, Heeg P. Surgical hand disinfection with a propanol-based hand rub: equivalence of shorter application times. $J$ Hosp Infect 2005; 59:304-310.

115. Kampf G, Ostermeyer C. Influence of applied volume on efficacy of 3minute surgical reference disinfection method prEN 12791. App Environ Microbiol 2004; 70:7066-7069.

116. Larson EL, Aiello AE, Heilman JM, et al. Comparison of different regimens for surgical hand preparation. AORN J 2001; 73:412-418.

117. Ojajärvi J, Mäkelä P, Rantasalo I. Failure of hand disinfection with frequent hand washing: a need for prolonged field studies. $J$ Hyg (London) $1977 ; 79: 107-119$.

118. Boyce JM, Kelliher S, Vallande N. Skin irritation and dryness associated with two hand-hygiene regimens: soap-and-water hand washing versus hand antisepsis with an alcoholic hand gel. Infect Control Hosp Epidemiol 2000; 21:442-448.

119. Larson E, Friedman C, Cohran J, Treston-Aurand J, Green S. Prevalence and correlates of skin damage on the hands of nurses. Heart Lung $1997 ; 26: 404-412$.

120. Larson E, Girard R, Pessoa-Silva CL, Boyce J, Donaldson L, Pittet D. Skin reactions related to hand hygiene and selection of hand hygiene products. Am J Infect Control 2006; 34:627-635.

121. Bissett L. Skin care: an essential component of hand hygiene and infection control. Br J Nurs 2007; 16:976-981.

122. Graham M, Nixon R, Burrell LJ, Bolger C, Johnson PD, Grayson ML. Low rates of cutaneous adverse reactions to alcohol-based hand hygiene solution during prolonged use in a large teaching hospital. Antimicrob Agents Chemother 2005; 49:4404-4405.

123. Winnefeld M, Richard MA, Drancourt M, Grob IJ. Skin tolerance and effectiveness of two hand decontamination procedures in everyday hospital use. Br J Dermatol 2000; 143:546-550.

124. Larson E, McGinley KJ, Grove GL, Leyden IJ, Talbot GH. Physiologic, microbiologic, and seasonal effects of handwashing on the skin of health care personnel. Am J Infect Control 1986; 14:51-59.

125. Scott D, Barnes A, Lister M, Arkell P. An evaluation of the user acceptability of chlorhexidine handwash formulations. J Hosp Infect 1991; 18 : 51-55.

126. Larson $E$, Killien M. Factors influencing handwashing behavior of patient care personnel. Am J Infect Control 1982; 10:93-99.

127. Ojajärvi J. The importance of soap selection for routine hand hygiene in hospital. J Hyg (London) 1981; 86:275-283.

128. Mayer JA, Dubbert PM, Miller M, Burkett PA, Chapman SW. Increasing handwashing in an intensive care unit. Infect Control 1986; 7:259-262.

129. Boyce JM. Antiseptic technology: access, affordability and acceptance. Emerg Inf Dis 2001; 7:231-233.

130. Pittet D, Allegranzi B, Sax H, Chraiti MN, Griffiths W, Richet H. Double-blind, randomized, crossover trial of 3 hand rub formulations: fasttrack evaluation of tolerability and acceptability. Infect Control Hosp Epidemiol 2007; 28:1344-1351.

131. Walsh B, Blakemore PH, Drubu YJ. The effect of handcream on the antibacterial activity of chlorhexidine gluconate. J Hosp Infect 1987; 9: 30-33.

132. Jones RD, Jampani H, Mulberry G, Rizer RL. Moisturizing alcohol hand gels for surgical hand preparation. AORN J 2000; 71:584-592.

133. Sartor C, Jacomo V, Duvivier C, Tissot-Dupont H, Sambuc R, Drancourt M. Nosocomial Serratia marcescens infections associated with extrinsic contamination of a liquid nonmedicated soap. Infect Control Hosp Epidemiol 2000; 21:196-199.

134. Brooks SE, Walczak MA, Malcolm S, Hameed R. Intrinsic Klebsiella pneumoniae contamination of liquid germicidal hand soap containing chlorhexidine. Infect Control Hosp Epidemiol 2004; 25:883-885.

135. Parasakthi N, Vadivelu J, Ariffin H, Iyer L, Palasubramaniam S, Arasu A. Epidemiology and molecular characterization of nosocomially transmitted multidrug-resistant Klebsiella pneumoniae. Int J Infect Dis 2000; 4: 123-128.

136. Pittet D, Simon A, Hugonnet S, Pessoa-Silva CL, Sauvan V, Perneger TV. Hand hygiene among physicians: performance, beliefs, and perceptions. Ann Intern Med 2004; 141:1-8.

137. Kohan C, Ligi C, Dumigan DG, Boyce JM. The importance of evaluating product dispensers when selecting alcohol-based handrubs. Am J Infect Control 2002; 30:373-375.

138. Dharan S, Hugonnet S, Sax H, Pittet D. Evaluation of interference of a hand care cream with alcohol-based hand disinfection. Occup Environ Dermatol 2001; 49:81-84.

139. Heeg P. Does hand care ruin hand disinfection? J Hosp Infect 2001; 48(suppl A):S37-S39.

140. Marchetti MG, Kampf G, Finzi G, Salvatorelli G. Evaluation of the bactericidal effect of five products for surgical hand disinfection according to prEN 12054 and prEN 12791. J Hosp Infect 2003; 54:63-67.

141. Grohskopf LA, Roth VR, Feikin DR, et al. Serratia liquefaciens bloodstream infections from contamination of epoetin alfa at a hemodialysis center. New Engl J Med 2001; 344:1491-1497.

142. Archibald LK, Corl A, Shah B, et al. Serratia marcescens outbreak associated with extrinsic contamination of $1 \%$ chlorxylenol soap. Infect Control Hosp Epidemiol 1997; 18:704-709.

143. Schwanitz HJ, Riehl U, Schlesinger T, Bock M, Skudlik C, Wulfhorst B. Skin care management: educational aspects. Int Arch Occup Environ Health 2003; 76:374-381.

144. McCormick RD, Buchman TL, Maki DG. Double-blind, randomized trial of scheduled use of a novel barrier cream and an oil-containing lotion for protecting the hands of health care workers. Am J Infect Control 2000; 28:302-310.

145. Berndt U, Wigger-Alberti W, Gabard B, Elsner P. Efficacy of a barrier cream and its vehicle as protective measures against occupational irritant contact dermatitis. Contact Dermatitis 2000; 42:77-80.

146. Ramsing DW, Agner T. Preventive and therapeutic effects of a moisturizer: an experimental study of human skin. Acta Derma Venereol $1997 ; 77: 335-337$.

147. Kampf G, Ennen J. Regular use of hand cream can attenuate skin dryness and roughness caused by frequent hand washing. BMC Dermatol 2006; 6:1.

148. Kotilainen HR, Brinker JP, Avato JL, Gantz NM. Latex and vinyl examination gloves: quality control procedures and implications for health care workers. Arch Intern Med 1989; 149:2749-2753.

149. Korniewicz DM, Laughon BE, Butz A. Integrity of vinyl and latex procedures gloves. Nurs Res 1989; 38:144-146.

150. Reingold AL, Kane MA, Hightower AW. Failure of gloves and other protective devices to prevent transmission of Hepatitis $B$ virus to oral surgeons. JAMA 1988; 259:2558-2560.

151. United States Occupational Safety and Health Administration. Occupational exposure to bloodborne pathogens. Fed Regist 2001; 66(12): 5317-5325. To be codified at 29 CFR 1910.1030.

152. Beltrami EM, Kozak A, Williams IT, et al. Transmission of HIV and hepatitis $\mathrm{C}$ virus from a nursing home patient to a health care worker. Am J Infect Control 2003; 31:168-175.

153. United States Centers for the Prevention and Control of Disease. Update: human immunodeficiency virus infections in health-care workers exposed to blood of infected patients. Morb Mortal Wkly Rep MMWR 1987; 36:285-289.

154. Patterson JE, Vecchio J, Pantelick EL, et al. Association of contaminated gloves with transmission of Acinetobacter calcoaceticus var. anitratus in an intensive care unit. Am J Med 1991; 91:479-483.

155. Bobulsky GS, Al-Nassir WN, Riggs MM, Sethi AK, Donskey CJ. Clostridium difficile skin contamination in patients with $C$. difficile-associated disease. Clin Infect Dis 2008; 46:447-450. 
156. Pittet D, Dharan S, Touveneau S, Sauvan V, Perneger TV. Bacterial contamination of the hands of hospital staff during routine patient care. Arch Intern Med 1999; 159:821-826.

157. Hagos B, Kibwage IO, Mwongera M, Muthotho JN, Githiga IM, Mukindia GG. The microbial and physical quality of recycled gloves. East Afr Med J 1997; 74:224-226.

158. Tietjen L, Bossemeyer $\mathrm{D}, \mathrm{McIntosh} \mathrm{N}$. Infection prevention guidelines for healthcare facilities with limited resources. Baltimore, $\mathrm{MD}$; Jhpiego, 2003.

159. Foca M, Jakob $\mathrm{K}$, Whittier S, et al. Endemic Pseudomonas aeruginosa infection in a neonatal intensive care unit. New Engl J Med 2000; 343: 695-700.

160. Moolenaar RL, Crutcher JM, San Joaquin VH, et al. A prolonged outbreak of Pseudomonas aeruginosa in a neonatal intensive care unit: did staff fingernails play a role in disease transmission? Infect Control Hosp Epidemiol 2000; 21:80-85.

161. Gordin FM, Schultz ME, Huber R, Zubairi S, Stock F, Kariyil J. A cluster of hemodialysis-related bacteremia linked to artificial fingernails. Infect Control Hosp Epidemiol 2007; 28:743-744.

162. Gupta A, Della-Latta P, Todd B, et al. Outbreak of extended-spectrum $\beta$-lactamase-producing Klebsiella pneumoniae in a neonatal intensive care unit linked to artificial nails. Infect Control Hosp Epidemiol 2004; 25 : 210-215.

163. Larson EL, Early E, Cloonan P, Sugrue S, Parides M. An organizational climate intervention associated with increased handwashing and decreased nosocomial infections. Behav Med 2000; 26:14-22.

164. Lankford MG, Zembower TR, Trick WE, Hacek DM, Noskin GA, Peterson LR. Influence of role models and hospital design on hand hygiene of healthcare workers. Emerg Infect Dis 2003; 9:217-223.

165. Tibballs J. Teaching hospital medical staff to handwash. Med J Aust 1996; 164:395-398.

166. Rosenthal VD, McCormick RD, Guzman S, Villamayor C, Orellano PW. Effect of education and performance feedback on handwashing: the benefit of administrative support in Argentinean hospitals. Am J Infect Control 2003; 31:85-92.

167. Benton $\mathrm{C}$. Hand hygiene-meeting the JCAHO safety goal: can compliance with $\mathrm{CDC}$ hand hygiene guidelines be improved by a surveillance and educational program? Plast Surg Nurs 2007; 27:40-44.

168. Pessoa-Silva CL, Hugonnet S, Pfister R, et al. Reduction of health care associated infection risk in neonates by successful hand hygiene promotion. Pediatrics 2007; 120:e382-390.

169. Trick WE, Vernon MO, Welbel SF, Demarais P, Hayden MK, Weinstein RA. Multicenter intervention program to increase adherence to hand hygiene recommendations and glove use and to reduce the incidence of antimicrobial resistance. Infect Control Hosp Epidemiol 2007; 28: $42-49$.

170. Ebnother C, Tanner B, Schmid F, La Rocca V, Heinzer I, Bregenzer T. Impact of an infection control program on the prevalence of nosocomial infections at a tertiary care center in Switzerland. Infect Control Hosp Epidemiol 2008; 29:38-43.

171. Whitby M, McLaws M-L, Ross RW. Why healthcare workers don't wash their hands: a behavioral explanation. Infec Control Hosp Epidemiol 2006; 27:484-492.

172. Sax H, Uckay I, Richet H, Allegranzi B, Pittet D. Determinants of good adherence to hand hygiene among healthcare workers who have extensive exposure to hand hygiene campaigns. Infect Control Hosp Epidemiol 2007; 28:1267-1274.

173. Whitby M, Pessoa-Silva CL, McLaws ML, et al. Behavioural considerations for hand hygiene practices: the basic building blocks. J Hosp Infect 2007; 65:1-8.

174. Gould DJ, Chudleigh JH, Moralejo D, Drey N. Interventions to improve hand hygiene compliance in patient care. Cochrane Database Syst Rev 2007:CD005186.

175. Aboelela SW, Stone PW, Larson EL. Effectiveness of bundled behavioural interventions to control healthcare-associated infections: a systematic review of the literature. J Hosp Infect 2007; 66:101-108.
176. Caniza MA, Maron G, Moore EJ, Quintana Y, Liu T. Effective hand hygiene education with the use of flipcharts in a hospital in El Salvador. $J$ Hosp Infect 2007; 65:58-64.

177. Lawton RM, Turon T, Cochran RL, Cardo D. Prepackaged hand hygiene educational tools facilitate implementation. Am J Infect Control 2006; 34: 152-154.

178. Duerink DO, Farida $\mathrm{H}$, Nagelkerke NJ, et al. Preventing nosocomial infections: improving compliance with standard precautions in an Indonesian teaching hospital. J Hosp Infect 2006; 64:36-43.

179. Huang TT, Wu SC. Evaluation of a training programme on knowledge and compliance of nurse assistants' hand hygiene in nursing homes. $J$ Hosp Infect $2008 ; 68: 164-170$.

180. Conly JM, Hill S, Ross J, Lertzman J, Louie TJ. Handwashing practices in an intensive care unit: the effects of an educational program and its relationship to infection rates. Am J Infect Control 1989; 17:330-339.

181. Dubbert PM, Dolce J, Richter W, Miller M, Chapman SW. Increasing ICU staff handwashing: effects of education and group feedback. Infect Control Hosp Epidemiol 1990; 11:191-193.

182. Raju TN, Kobler C. Improving handwashing habits in the newborn nurseries. Am J Med Sc 1991; 302:355-358.

183. Rosenthal VD, Guzman S, Safdar N. Reduction in nosocomial infection with improved hand hygiene in intensive care units of a tertiary care hospital in Argentina. Am J Infect Control 2005; 33:392-397.

184. Zerr DM, Allpress AL, Heath J, Bornemann R, Bennett E. Decreasing hospital-associated rotavirus infection: a multidisciplinary hand hygiene campaign in a children's hospital. Pediatr Infect Dis J 2005; 24:397-403.

185. Eldridge NE, Woods SS, Bonello RS, et al. Using the Six Sigma process to implement the Centers for Disease Control and Prevention Guideline for Hand Hygiene in 4 intensive care units. I Gen Intern Med 2006; 21(suppl 2):S35-S42.

186. Harbarth S, Pittet D, Grady L, et al. Interventional study to evaluate the impact of an alcohol-based hand gel in improving hand hygiene compliance. Pediatr Infect Dis $J$ 2002; 21:489-495.

187. Brown SM, Lubimova AV, Khrustalyeva NM, et al. Use of an alcoholbased hand rub and quality improvement interventions to improve hand hygiene in a Russian neonatal intensive care unit. Infect Control Hosp Epidemiol 2003; 24:172-179.

188. McGuckin M, Waterman R, Porten L, et al. Patient education model for increasing handwashing compliance. Am J Infect Control 1999; 27: 309-314.

189. McGuckin M, Waterman R, Storr IJ, et al. Evaluation of a patientempowering hand hygiene programme in the UK. J Hosp Infect 2001; 48: 222-227.

190. McGuckin M, Taylor A, Martin V, Porten L, Salcido R. Evaluation of a patient education model for increasing hand hygiene compliance in an inpatient rehabilitation unit. Am J Infect Control 2004; 32:235-238.

191. Suresh G, Cahill J. How "user friendly" is the hospital for practicing hand hygiene? An ergonomic evaluation. Jt Comm J Qual Patient Saf 2007; 33:171-179.

192. Ogunsola FT, Adesiji YO. Comparison of four methods of hand washing in situations of inadequate water supply. West Afr J Med 2008; 27: 24-28.

193. Larson E, Silberger M, Jakob K, et al. Assessment of alternative hand hygiene regimens to improve skin health among neonatal intensive care unit nurses. Heart Lung 2000; 29:136-142.

194. Voss A, Widmer AF. No time for handwashing!? Handwashing versus alcoholic rub: can we afford $100 \%$ compliance? Infect Control Hosp Epidemiol 1997; 18:205-208.

195. Pittet D. Compliance with hand disinfection and its impact on hospitalacquired infections. J Hosp Infect 2001; 48(suppl A):S40-\$46.

196. Girou E, Oppein F. Handwashing compliance in a French university hospital: new perspective with the introduction of hand-rubbing with a waterless alcohol-based solution. J Hosp Infect 2001; 48(suppl A):S55S57.

197. Ritchie K, Iqbal K, Macpherson K, Riches E, Stout A. The provision of alcohol based products to improve compliance with hand hygiene. 
Health technology assessment report. Edinburgh, UK: National Health Service Quality Improvement Scotland, 2005.

198. Larson EL, Quiros D, Lin SX. Dissemination of the CDC's Hand Hygiene Guideline and impact on infection rates. Am I Infect Control 2007; 35:666-675.

199. Haley RW, Culver DH, White JW, Morgan WM, Emori TG. The efficacy of infection surveillance and control programs in preventing nosocomial infections in U.S. hospitals. Am J Epidemiol 1985; 121:182-205.

200. Grayson ML, Jarvie LJ, Martin R, et al. Significant reductions in methicillin-resistant Staphylococcus aureus bacteraemia and clinical isolates associated with a multisite, hand hygiene culture-change program and subsequent successful statewide roll-out. Med J Aust 2008; 188:633-640.

201. World Health Organization (WHO). WHO Guidelines on drinkingwater quality. First addendum to 3rd ed. Geneva, Switzerland: World Health Organization, 2006.

202. National Patient Safety Agency. Achieving our aims: evaluating the results of the pilot "cleanyourhands" campaign. London, UK: National Patient Safety Agency, 2004.

203. Wachter RM, Pronovost PJ. The 100,000 Lives Campaign: a scientific and policy review. It Comm J Qual Patient Saf 2006; 32:621-627.

204. Stone $S$, Slade R, Fuller $C$, et al. Early communication: does a national campaign to improve hand hygiene in the NHS work? Initial English and Welsh experience from the NOSEC study (National Observational Study to Evaluate the "CleanYourHands" Campaign). $J$ Hosp Infect 2007; 66:293-296.
205. National Patient Safety Agency. CleanYourHands campaign, 2007. Available at http://www.npsa.nhs.uk/cleanyourhands/. Accessed April 23, 2009.

206. Richet HM, Benbachir M, Brown DE, et al. Are there regional variations in the diagnosis, surveillance, and control of methicillin-resistant Staphylococcus aureus? Infect Control Hosp Epidemiol 2003; 24:334-341.

207. Patient safety alert 04: clean hands help to save lives. London, UK: $\mathrm{Na}$ tional Patient Safety Agency, 2004.

208. Sandora TJ, Shih MC, Goldmann DA. Reducing absenteeism from gastrointestinal and respiratory illness in elementary school students: a randomized, controlled trial of an infection-control intervention. Pediatrics 2008; 121:e1555-1562.

209. Morton JL, Schultz AA. Healthy hands: use of alcohol gel as an adjunct to handwashing in elementary school children. $J$ Sch Nurs 2004; 20: 161-167.

210. White C, Kolble R, Carlson R, et al. The effect of hand hygiene on illness rate among students in university residence halls. Am J Infect Control 2003; 31:364-370.

211. Hammond B, Ali Y, Fendler E, Dolan M, Donovan S. Effect of hand sanitizer use on elementary school absenteeism. Am J Infect Control 2000; 28:340-346.

212. Camins BC, Fraser VI. Reducing the risk of health care-associated infections by complying with $\mathrm{CDC}$ hand hygiene guidelines. ft Comm J Qual Patient Saf 2005; 31:173-179. 